\title{
TIPOGRAFÍAS DESOBEDIENTES
}

\author{
José Gabriel MARTÍNEZ GARCÍA \\ María Sonia DÍAZ JIMÉNEZ \\ Colectivo Un mundo feliz (Madrid) \\ La palabra «diseñada» tiene el doble de \\ potencia que la palabra pronunciada.
}

Un Mundo Feliz.

\section{$\mathbf{I}$}

\section{ntroducción}

Según Gaston Bachelard (1964) desobedecer es una forma de actuar que está implícita en todo espíritu creativo. Exige la autonomía del desobediente y está abocada tarde o temprano al castigo. ¿Pero, entonces, cuál es el sentido, si es que lo tiene, de la desobediencia tipográfica? Nuestra hipótesis es que cuando la palabra es radicalmente desobediente y cuestionadora exige una tipografía formal y conceptualmente crítica convirtiéndose en una herramienta de desmontaje, transgresión, apropiación y subversión que construye una cultura visual alternativa y militante que trata de influir en la esfera pública.

En este texto analizaremos la tipografía desde una perspectiva comunicativa-crítica como una manifestación de interés social y público, e intentaremos acercarnos al activismo gráfico como una herramienta de resistencia que a través de la forma tipográfica aumenta la intensidad de la comunicación autónoma, social y cultural.

Aplicando distintos parámetros activistas observaremos que la tipografía es una manifestación afectivista, un dispositivo de gran potencia para el activismo gráfico. Es un recurso visual de representación que lucha por defender los corazones y las mentes de las personas. Su estética es múltiple, apropiacionista y muchas veces, anónima. Es depropiación, un diseño-de-diseños con mensajes heterogéneos en su forma y temática. Se mueve por el efecto eros, una fuerza intuitiva solidaria y disidente. Es una contra-manipulación estratégica y táctica que funciona como respuesta a una manipulación anterior. Y siempre que presenta una implicación con lo social y lo político es colectiva, lo que provoca un constructivismo activista, una identidad social, emocional y solidaria que se mantiene a lo largo del tiempo. 


\section{Objetivos y metodología}

Nuestro objetivo es identificar el papel de la tipografía como una herramienta para la reflexividad social, política y cultural en el diseño gráfico. Para ello utilizaremos la teoría crítica y activista intentando establecer conexiones que enmarquen el tema. La aparición del «diseño crítico» y la «práctica crítica» (Dunne y Raby, 2014) en el diseño ha permitido un cambio de paradigma que nos permite definir nuevas formas de pensar y actuar. Ahora bien, nuestra tarea es especulativa y no se propone como algo sistemático, en todo caso, como un análisis de métodos, configuraciones y propósitos que doten de significado y comprensión a la práctica. Una práctica que llevamos ejerciendo como colectivo más de quince años.

Como esta investigación se enmarca dentro del diseño crítico y especulativo desde la perspectiva del compromiso cultural, se ha utilizado una metodología hermenéutica para construir un marco conceptual que dote de significado y comprensión a la práctica. Con este acercamiento al debate social buscamos abrir nuevas líneas teóricas y creativas para la comunicación visual activista desde la perspectiva tipográfica.

\section{DESOBEDIENCIA}

\section{Un diseño crítico}

La tipografía no funciona de manera independiente. La cultura visual y material de nuestro tiempo nace de las interrelaciones y los contextos (Julier, 2010). El diseño activista adquiere su sentido en la práctica y la circulación de los mensajes en el espacio público. La creación de valor que propone no es la ortodoxa, centrada en lo comercial, sino la cultural, social y política. Se presenta como un ejercicio de valor simbólico crítico.

Siguiendo los estudios de Malpass (2012: 15) podemos observar tres tipos característicos de prácticas: el diseño asociativo que nace de las formas políticas radicales y del anti-diseño, cuya finalidad es desarrollar un mecanismo de subversión y experimentación propio del arte conceptual; el diseño especulativo que camina de la mano de la ciencia y las tecnologías emergentes, y permite la construcción de teorías socio-científicas; y el diseño crítico que da lugar a una crítica socio-cultural, es distópico y en sus prácticas visualiza una utopía negativa a través de comentarios sociales.

Los diseñadores «críticos» se plantean incorporar su trabajo dentro de una práctica general que supere las fronteras del diseño comercial (Fallman, 2008) [fig1]. Su posición se propone como una práctica democrática, enfocada al debate y superadora de la creatividad más personal. Este modelo se mueve por una voluntaria insubordinación crítica y plantea una alternativa contra la producción capitalista donde está integrada (Thackara, 2000: 22). El diseño crítico propone romper el marco a través de la investigación sobre la percepción y el funcionamiento de los diseños y su uso. Dunne y Raby en su texto Towards a Critical Design destacan que estas prácticas críticas son profundamente especulativas y no tienen nada que ver con lo comercial o el marketing sino que hay que observarlas desde una perspectiva filosófica y reflexiva. La potencialidad del diseño crítico se define en su 


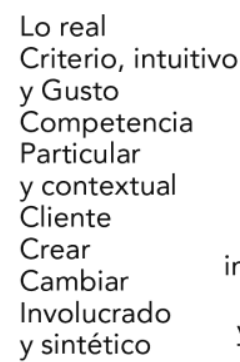

Contexto particular y sintética impulsado,

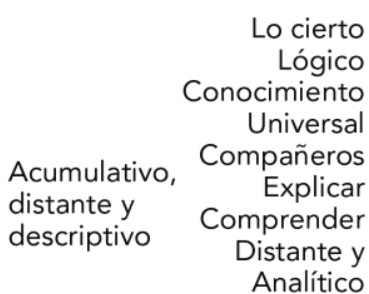

estudios de diseño

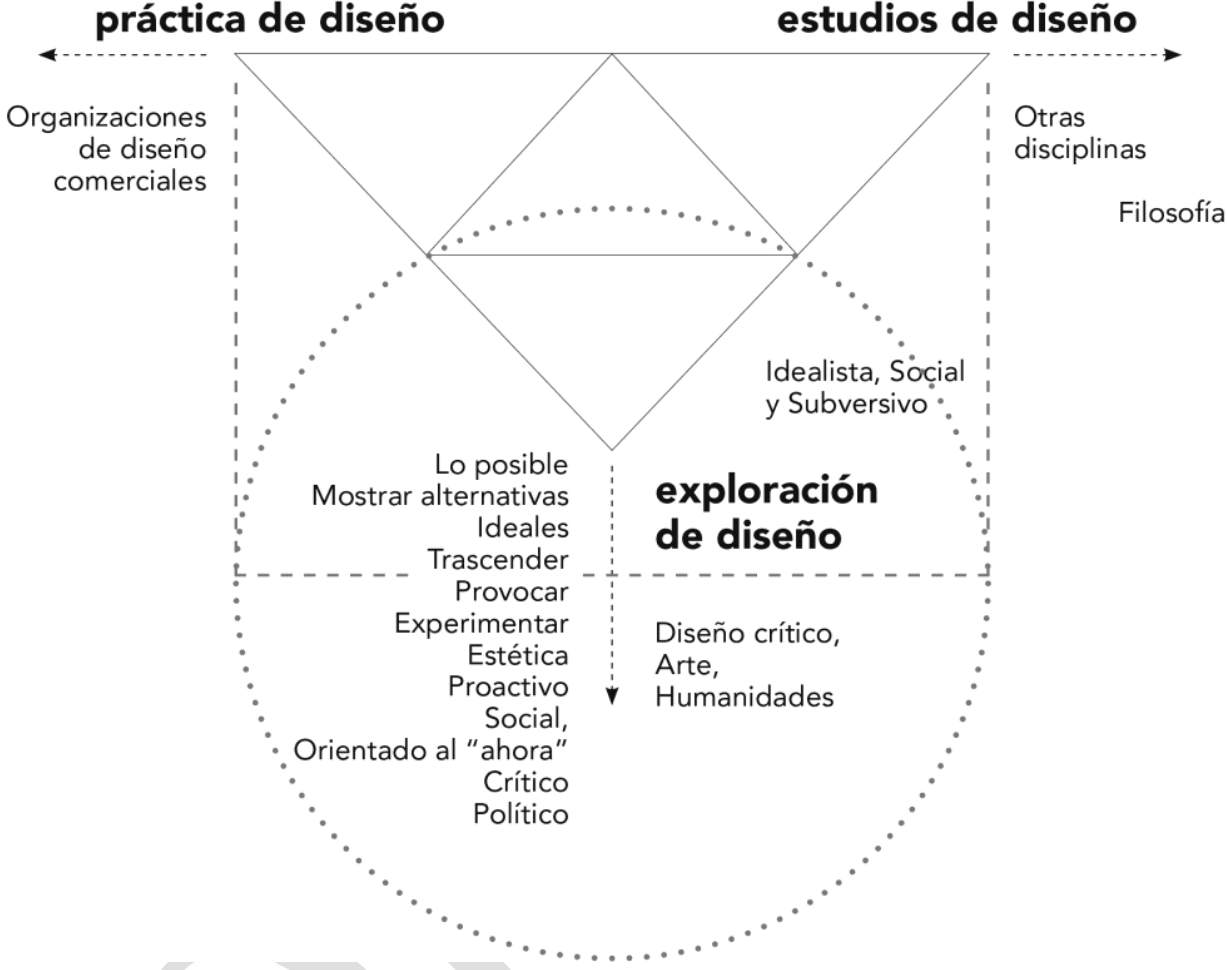

Fig. 1. El triángulo de la investigación del diseño de interacción. Fuente: Fallman, 2008.

funcionamiento como facilitador entre público y expertos, como generador de debate entre consumidores-ciudadanos, como constructor de escenarios y futuros alternativos. En este sentido, la función del diseño especulativo y crítico es hacer pensar y ayudarnos a plantear los futuros más deseables.

\section{Activismo!}

Para Tim Jordan, la ética «activista!» contiene un compromiso con una democracia radical que tiene visión de futuro. El «activismo! es esencialmente algo hecho junto a muchas personas» (Jordan, 2001: 12) que comparten una identidad y se solidarizan en la búsqueda de la transgresión. Esta solidaridad es la que hace que las personas conecten sus miedos, esperanzas, ira y cualquier otra emoción mientras están comprometidas en una acción transgresora des/organizada. Gavin Brown y Jenny Pickerill (2009: 34) destacan la importancia de una «sostenibilidad emocional» para que se pueda mantener un equilibro entre los sentimientos personales y los colectivos en la práctica del 
activismo. Alberto Melucci (1996: 70) plantea que esa construcción social que nace de la acción colectiva de los movimientos sociales adquiere identidad gracias a un «constructivismo» emocional y solidario, y George Katsiaficas, que el nuevo activismo se guía por una gramática de la autonomía, desmercantilización y solidaridad denominada «efecto eros» que desata una energía erótica que es capaz de unir a las personas mediante unos fuertes lazos de intimidad solidaria (Katsiaficas, 2010: 17).

\section{La protesta y persuasión noviolentas}

La comunicación visual es un modo de acción política noviolenta que tiene lugar a través de los mensajes y las imágenes que se han expandido, principalmente, de manera informal mediante manifestaciones, talleres, exposiciones y galerías on-line. Así, cada colectivo político e incluso cada activista defienden una forma de expresión propia. La comunicación visual se sitúa frente a la información mediática y entiende que la creatividad visual, si no toma parte de un proceso comunicativo adecuado no es útil a las causas. Es un ejercicio de presión noviolento que se enmarca dentro de «una estrategia de acción política» (Castañar, 2010: 13) a la que sirve de complemento. Para Gene Sharp el activismo gráfico está incluido dentro de su lista de métodos de persuasión y protesta noviolentas que denomina «comunicación con un público más amplio» y está constituido por distintas manifestaciones como son las «consignas, caricaturas y símbolos (escritos, pintados, dibujados, impresos, ademanes, hablados, o fingidos). Estandartes, carteles y desplegados. Volantes, folletos, libros. Periódicos y revistas» (Sharp, 2014: 30).

Los ciudadanos-diseñadores pueden aportar sus conocimientos - reflexión autónoma- y energía - estado emocional- para influir en la percepción e interpretación de la opinión pública — consenso con los demás-. Según Gene Sharp (1988) el diseño de carteles, símbolos, pancartas y folletos es una herramienta muy importante para ejercer la protesta y persuasión noviolentas, porque permite la comunicación con un público más amplio. Opinar es una manera de responder, desde el encargo o de forma independiente y libre, mediante el uso de la libertad de expresión a cuestiones que preocupan al diseñador en una sociedad democrática. El diseño puede servir para provocar procesos de crítica. El artista islandés Olafur Eliasson (2012) considera que cualquier estructura debería tener un pequeño parlamento, un lugar para la confrontación y el debate; que el museo, la universidad y el estudio del diseñador/artista deben ser plataformas de discusión.

Desde las experiencias colectivas del 68, el diseño gráfico ha mantenido una tradición humanista aplicada al campo del servicio público que hoy día está tomando una importancia inusitada. En la actualidad, los diseñadores se implican de forma personal o en grupo para mostrar y distribuir sus trabajos involucrados al servicio de una verdad comprometida con la cohesión social y la protesta política. Los propios diseñadores se han convertido en agentes que estimulan la difusión e intercambio de ideas y promueven el surgimiento de un pensamiento social crítico; saben que su opinión es importante porque puede influir en la percepción de la sociedad acerca de diferentes cuestiones que están en la agenda social y política. Nos lo recuerda Jorge Frascara (2004: 23) cuando afirma que «el 
diseño de comunicación visual se ocupa de la construcción de mensajes visuales con el propósito de afectar el conocimiento, las actitudes y el comportamiento de la gente». Por ello es importante destacar que los diseñadores cuando actúan como activistas se convierten en productores de subjetividades.

\section{El ciudadano-diseñador}

La desobediencia no es sólo una cuestión que atañe al individuo, es un asunto colectivo que corresponde al bien común. Según el colectivo activista francés Formes Vives, el diseño es un trabajo que aúna la investigación y la crítica, un paso fronterizo para una práctica lúcida de la comunicación visual y política. El ciudadano-diseñador utiliza sus diseños aplicándolos a los «intereses públicos, intereses generales». Ellos proponen una práctica desobediente con los cánones comerciales y los intereses privados de manera que se puedan cuestionar conceptos tales como el espacio público, el interés público y la comunicación pública. Lo ejemplifican al analizar la imagen de la política y señalar cómo «los creadores de las imágenes municipales, con frecuencia, tienen la tarea de embellecer el orden, cuando deberían iniciar el desorden de los intereses públicos y generales» (Formes Vives, 2008). La responsabilidad del ciudadano-diseñador es cuestionar la representación y nunca sentirse impotente. En un mundo que está configurado por una ingente cantidad de imágenes, no hay una única verdad y las formas de intercambio social se cambian e inventan con cada nuevo paso que damos.

Si consideramos esta perspectiva, la tipografía puede ser una forma política de practicar la comunicación visual no-comercial. Una tipografía que se crea y se utiliza desde la perspectiva del uso público: instituciones, colectivos activistas y diseñadores que producen su trabajo alejándose de los tópicos del mercado. Ciudadanos-diseñadores que buscan propuestas expresivas y discursos donde lo político, lo social y lo cultural caminen de la mano sin complejos. Una forma tipográfica insolente que trata de legitimar una posición anti-comercial, es decir, resistente a la lógica liberal de la sociedad de consumo, y propone una práctica lúcida e imaginativa de la comunicación visual y política (Formes Vives, 2008). Esta manera de entender que el diseñador es un ciudadano mantiene los valores heredados de la Revolución Francesa y es promovida de manera ejemplar por diseñadores y colectivos franceses como Gérard Paris-Clavel/Ne pas plier, Vincent Perrottet/les Graphistes Associés, Sebastian Marchal/la Nuit Debout y el colectivo Formes Vives.

\section{SUBVERSIÓN}

\section{La tipografía institucionalizada y su subversión}

La tipografía participa del simulacro visual institucionalizado y es un atributo formal del orden y la repetición. Las letras se disponen para construir micro-mundos sociales controlados, son expresiones gráficas de los códigos de la vida y las relaciones sociales. Su elaboración nace de una racionalización estética que trata de canalizar todos los aspectos de nuestra vida. El uso institucionalizado de la tipografía crea un monólogo estandarizado y promueve una memoria colectiva 
que tiende a lo impersonal y huye de los conflictos. Está diseñada para «hacer callar» (Attali, 1995: 34) las auténticas voces y conflictos humanos.

Las tipografías desobedientes tienen una capacidad de intervención simbólico-cultural y transgresora que está aún por descifrar. El uso consciente de la palabra y su formalización tipográfica puede ser una herramienta de interferencia cultural — culture jamming-, siempre y cuando el uso insolente del diseño cuestione toda dependencia institucional y se proponga como una invitación a la responsabilidad. Este uso de la tipografía como herramienta activista trata de subvertir las formas, descubrir su irracionalidad y desenmascarar los mecanismos del poder, aportando una mirada política. Al surgir de un acto no comercial propone un modelo social radical de creación y disfrute autónomo [fig. 2].

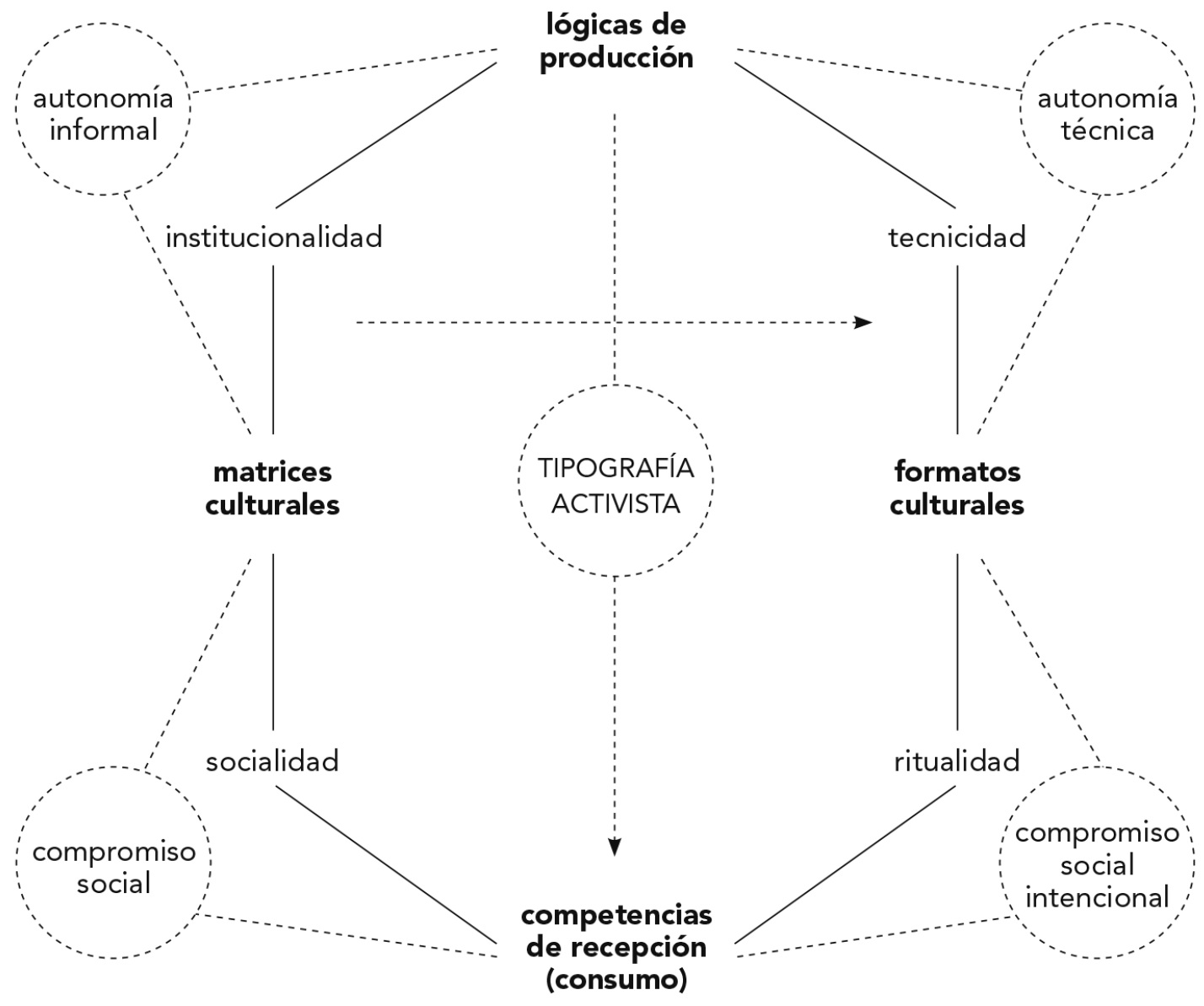

Fig. 2. Mapa de mediaciones elaborado a partir de Martín-Barbero, 2002. Fuente: elaborado a partir de Escosteguy (2008: 158).

La interferencia sobre la tipografía institucionalizada aporta una marginalidad política y cultural. Provoca una anti-armonía a través de su relación replicante e imitadora del original. La insolencia que provoca la manipulación del original evidencia que parafrasear, copiar, falsificar, revalidar, son herramientas esenciales de una crítica visual basada en la praxis de una reutilización continuada de 
conceptos e imágenes para la construcción de nuevas constelaciones utópicas. Porque el valor de la tipografía insolente no es estético sino estratégico y su finalidad es provocar el conflicto.

El éxito de la tipografía comercial se basa en una repetición que «crea un sistema de valores apolítico, a-conflictual, idealizado» (Attali 1995, 163). Sin embargo, la aparición de una tipografía insolente produce la rebeldía ante unas formas tipográficas trivializadas que han sido domesticadas como consumo. El efecto crítico que provoca trata de despertar las conciencias utilizando y las propias letras que han sido mercantilmente anestesiadas. En este sentido, tener un ética tipográfica clara puede darnos la solución. El diseñador Didac Ballester propone una Licencia para un uso ético de la tipografía:

1. Esta tipografía está diseñada para dejar sin palabras a la guerra, por eso se prohíbe su uso para escribir declaraciones de guerra.

2. Está prohibido utilizar esta tipografía para escribir mandatos que permitan el uso de la fuerza contra la población civil.

3. Esta tipografía no podrá ser utilizada por gobiernos que practiquen la pena de muerte, la tortura, tratos crueles, inhumanos o degradantes.

4. Queda terminantemente prohibido el uso de esta tipografía en textos que apoyen la desigualdad entre las personas por razón de raza, nacionalidad, sexo, religión y orientación sexual.

5. Esta tipografía está diseñada para escribir palabras, palabras libres con las que construir pensamientos e ideas, por eso se prohíbe su uso a los gobiernos de los países en los que no exista la libertad de expresión y no se permita la libertad de pensamiento y de conciencia.

\section{Apropiación/depropiación tipográfica}

Una de las tácticas más utilizadas por el activismo visual consiste en apropiarse/falsificar/imitar/engañar algo que ya existe. Este mecanismo funciona gracias a su poder de sobreidentificación. Según Marcus Boon (2013: 31) el valor cultural y social de la copia y la «depropiación»-ejercicio de sustracción que mantiene un doble movimiento contradictorio de apropiación-expropiación — se basa en su potencial para modelar otras formas de sociabilidad. Así, la depropiación tipográfica es un dispositivo que favorece la libertad de expresión mediante el ejercicio creativo de las contra-apropiaciones con el fin de hacer surgir lo propio. Por otro lado, la apropiación está íntimamente ligada al regalo, al obsequio, a la donación del ser último de las cosas. La depropiación tipográfica permite que las formas y su uso sucedan de forma libre, sin imponer normas o condiciones cerradas, funcionando como un flujo de ser que manifiesta indiferencia a poseer. Esta idea pertenece a una ética de la donación que se opone a la propiedad. Es una forma de renuncia que lleva a la liberación y a la independencia de las personas y las cosas y, en este caso, de la tipografía. 
La depropiación tipográfica aporta un sentido de improvisación, temporalidad y tergiversación subversiva que puede ser muy útil para el activismo. Marcus asegura que «depropiación significa aprender a relajarse» (Boon, 2013: 230), pues al eliminar el uso exclusivo o privilegiado de algo, lo estamos abriendo al uso de muchos más. Surge así la posibilidad de reapropiación de una riqueza que sólo les pertenecía a algunos. La filosofía activista que promueve el intercambio libre de la cultura defiende que estas apropiaciones son posibles, que la nueva lógica de la «multitud» y sus formas de vida (Virno, 2003: 42) como lugar común es el «disfrute de la copia». El valor más subversivo de la copia-como-regalo es que es barata-gratuita e inútil en un sentido utilitario — comercial- $\mathrm{y}$, sin embargo, tiene una potencialidad expresiva basada en la improvisación, en las experiencias encontradas que provoca.

\section{El sentido del humor tipográfico}

Nuestra sociedad posmoderna es humorística (Lipovetsky, 1986: 136), el humor impregna todos los ámbitos de nuestra vida, de la cultura a la política, y elimina la separación entre lo serio y lo cómico. Como lo lúdico y hedonista triunfa, esta situación ha generado un fenómeno de banalización que pone en cuestión la potencia crítica y activista del humor convirtiéndolo en algo inofensivo. Cuando la risa es un objeto de consumo su valor subversivo baja y su utilización para las causas sociales y políticas exige ser revisada.

El humor como actitud crítica de cuestionamiento cultural, político y social es una herramienta fundamental del activismo visual. El humor no se puede separar del contexto social en el que se emplea. Es un potente transmisor de pensamiento. El humor es un estado de ánimo y una actitud ante la vida. Y como sus posibilidades son muchas, la pregunta que nos hacemos es si existe un humor combativo, un humor que se adapte a las necesidades del activismo visual y que se transmita de forma natural a través de la tipografía. En este sentido, y siguiendo las hipótesis de Hernández Muñoz (2008: 27) se puede interpretar que un uso de lo tipográfico como pura comicidad, es decir, como juego superficial, no puede ser considerado activista, ya que su función principal es divertir y provocar la risa como un entretenimiento. Sin embargo, cuando el humorismo tipográfico nace del escepticismo, de las insuficiencias humanas, del sentimiento de lo contrario y su función es hacer pensar a través de la risa o de la tristeza, entonces sí podemos considerarlo un instrumento de la verdad liberadora que desmonta certezas, un humor crítico y contestatario que lo cuestiona todo.

Siguiendo los estudios de Lipps (2015) podríamos observar varios tipos de humorismo tipográfico. El humor humorístico que busca desconcertar desde la libertad mediante la subversión de la norma social, sus valores y costumbres. Y el humor satírico que es moralizador, burlesco y lúdico; sus herramientas son la ridiculización y la farsa con la finalidad de atacar la realidad provocando la indignación a través de la sátira, la burla, la parodia, la caricatura, lo grotesco, el humor negro, el sarcasmo, el absurdo y la ironía. 


\section{Estética activa (estilo-forma-efecto)}

La creatividad activista no permite separar la forma del contenido y el efecto del significado político porque todos están inevitablemente unidos. El concepto de estilo que nos interesa implica que la forma es el mensaje y que sirve para dar la forma apropiada para persuadir con eficacia. No hay significado neutro, la forma es el efecto y el efecto es el mensaje. Según Krøijer (Jacobi 2012, 137) cada argumento produce un significado y el efecto de la forma produce una imagen. Sin embargo, muchas veces a los comunicadores gráficos se les olvida que una imagen no puede ser un argumento. Este problema surge cuando aplicamos un significado político a un diseño determinado. Sabemos que toda imagen está abierta a la libre interpretación por lo que no puede ser un argumento. Podemos utilizar su efecto pero es difícil mantener su significado. Por lo tanto, hay que asumir que ésta es la principal debilidad de las imágenes activistas.

\section{La recursividad como modelo creativo}

El concepto de recursividad está ligado a la repetición. Pero la recursividad necesita para repetirse que ocurra algo previamente y de esta manera se asocia con otras repeticiones anteriores y posteriores. Según Padilla (2012: 43-44), la recursividad es un gran recurso creativo porque produce algo nuevo a través de las repeticiones consecutivas. En el diseño de comunicación hay recursividad cuando se anidan mensajes e imágenes dentro de otras frases e imágenes en cadenas potencialmente infinitas. En un sistema recursivo las partes poseen propiedades que las transforman en una totalidad. Los elementos son independientes y sin embargo comparten las mismas características que el sistema total. Su forma de crecer es integrando elementos en una totalidad más amplia. Las consecuencias de un sistema recursivo es que elimina jerarquías, ya que cada fragmento es un todo completo. Se presenta como algo abierto que continuamente se replica y multiplica. Permite construir imágenes y mensajes potencialmente infinitos a partir de un número limitado de recursos.

Las imágenes tienen una capacidad expansiva ilimitada. El contenido y los objetivos de la comunicación activista se formalizan utilizando una retórica y estética política significante en sintonía con la sociedad y producen una imagen mucho más grande que la que aportaría un artista o diseñador que actuara de forma independiente. Esta idea de las imágenes expansivas permite pensar y actuar como grupo, de forma colectiva y colaborativa para que sea posible una comunicación política simbólica.

\section{Bricolaje/zona autónoma temporal}

La lucha juvenil, la lucha callejera y la militancia son los tres elementos definitorios para construir la autonomía. Esta tensión permite una suspensión momentánea de los valores capitalistas fomentando un nuevo espacio de intercambio. La barricada es una especie de «bricolaje», según los situacionistas, donde las personas pueden actuar y se da una situación de empoderamiento. Esta desviación es breve, temporal, inestable, peligrosa cuya energía no está sometida a control (Jacobi, 
2012: 26). La barricada activista construye una frontera temporal marcada por lo que Paolo Virno denomina un «éxodo» de la sociedad que se mueve hacia un nuevo paisaje urbano, una «zona autónoma temporal» según el concepto desarrollado por Hakim Bey.

Por otra parte, el «collage» y el fotomontaje son manifestaciones gráficas de esa conciencia que se crea en una «zona autónoma temporal». Para Bañuelos (2008: 117) el fotomontaje revolucionario tiene la función de «poner al descubierto implacablemente la realidad social» y es un método que no busca la belleza gráfica o pictórica sino la realización de una conciencia política y una visión global revolucionaria (DURUS, 1989).

\section{DESASTRA!}

\section{DESmontaje/Apropiación/Subversión/TRAnsgresión según el colectivo Un mundo feliz}

En los proyectos visuales, que realizamos desde 2002, esperamos expresar nuestras preocupaciones y esperanzas. En tanto miembros de una comunidad y de una cultura determinadas no podemos dejar de expresar, aunque queramos lo contrario, los contenidos propios de esa unidad sin costuras. En nuestros diseños pretendemos dar sentido al mundo poniendo en evidencia lo mejor de nuestra existencia pero, para ello, debemos poner en evidencia todo aquello que hace imposible dicha aspiración. Es decir, expresar no sólo lo bueno y maravilloso de la vida sino, también, denunciar todo aquello que vaya contra ella: la injusticia, la arbitrariedad, el ultraje, la infamia y todas aquellas iniquidades que asume el odio y la muerte. Por ello, nuestro trabajo asume un carácter de reivindicación, de reclamo, de política en el buen sentido, tratando de influir, en lo posible, en la restitución de la justicia y la dignidad. - Un Mundo feliz (después de Clemente Padín)

Después de haber analizado algunas cuestiones referentes a la desobediencia y la insolencia, ahora nuestra intención es explicar cómo el colectivo Un mundo feliz (a partir de ahora UMF) entiende y utiliza el sistema tipográfico en el activismo gráfico. UMF denomina su trabajo como diseño popular bastardo, una forma de activismo visual que aglutina la acción cultural directa, la metodología del hazlo-tú-mismo y la simplicidad del signo gráfico para expresar situaciones precarias.

Una idea clave del proyecto desobediente es tomar la tipografía, ante todo, como palabra y el diseño de la palabra como arma. Para UMF el diseño popular bastardo es un puré visual que surge de remezclas y los modos de producción colectiva, que introduce la tipografía dentro de la acción política, que inventa nuevas formas de aplicación, activando herramientas/mecanismos/recursos, que cuestionan las prácticas, que presenta procesos fáciles de aplicar y que defiende la autoposesión como una liberación del rigor del diseño profesional que fomenta el amateurismo práctico.

Durante más de quince años UMF ha utilizado la tipografía desarrollando su carácter más crítico, tanto desde la perspectiva de los nuevos modos de construcción como su aplicación práctica. Así, mientras muchos señalan la necesidad de nuevas formas de acción fruto de las sensibilidades globales, UMF defiende que hay muchas propuestas que están aún por desarrollar, ya que el diseño tipográfico permite al usuario una continua autorrealización y unas posibilidades ilimitadas si se muestra 
atrevimiento creativo. La tipografía actual representa un collage vital de historias, revisiones, mezclas, variaciones, interpretaciones y usos. Frente a otras épocas, la tipografía del siglo XXI es una tipografía de la praxis, una negociación entre cultura, política, economía, ética y estética. Es una construcción del diseño que opera desde una conectividad-colaboración de alto contacto y participativa. En estos momentos está revitalizándose una nueva perspectiva social de implicación democrática y de dominio público, y la tipografía está llamada a unirse a este movimiento liberador y provocador.

\section{Tipografía bastarda post-experimental}

Para los diseñadores activistas posmodernos el concepto de originalidad no es relevante y lo viven bajo las múltiples formas del simulacro como representación de la realidad (Baudrillard, 1984). De esta forma se ponen en valor la cultura popular, el amateurismo, la mezcla y lo bastardo. Según Chistopher Reed

[...] en vez de fingir una originalidad, el posmoderno se concentra en la manera en que las imágenes y los símbolos (significante) cambian o pierden su significado cuando se sitúan en contextos diferentes (apropiados), que revelan (deconstruyen) los procesos mediante los cuales el significado es construido (Reed, 1982: 272).

Otro referente que se aprecia en los proyectos de UMF son ciertas influencias feministas en el uso de la palabra, la fragmentación y los valores comunitarios/colectivos, ya que como señala Lucy Lippard «damos por sentado que hacer arte no es tan sólo expresarse uno mismo, sino que es una tarea mucho más amplia y más importante: expresarse uno mismo como miembro de una unidad mayor o una com/unidad» (Lippard, 1980, citado en Reed, 1982: 277).

Un buen ejemplo de estas preocupaciones se manifiestan es la fuentes Pepita Analfaveta, VIHvo font y en Stencil Mix [Figs. 3, 4, 5 y 6]. La manera de diseñar/actuar seguida por UMF tiene una herencia posmoderna. Para ellos todo es relativo y frágil. No aceptan ninguna realidad absoluta, autónoma y suficiente, de manera que todas las palabras e imágenes son intercambiables y se rigen por una existencia contradictoria, el diseño como collage, porque la escritura postmoderna es collage intertextual donde todo vale (Octavi Fullat, 2002).

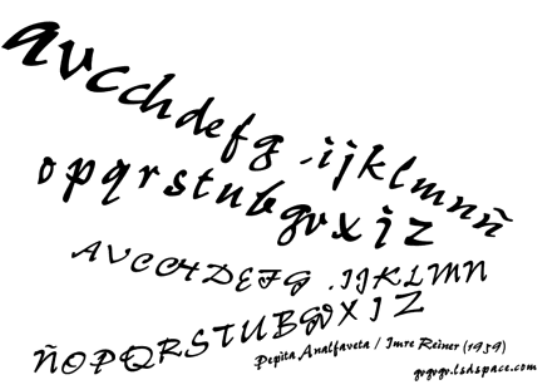

Fig. 3. Pepita Analfaveta elaborada a partir de de Imre Reiner. Fuente: Un mundo feliz / Political types, 2005.
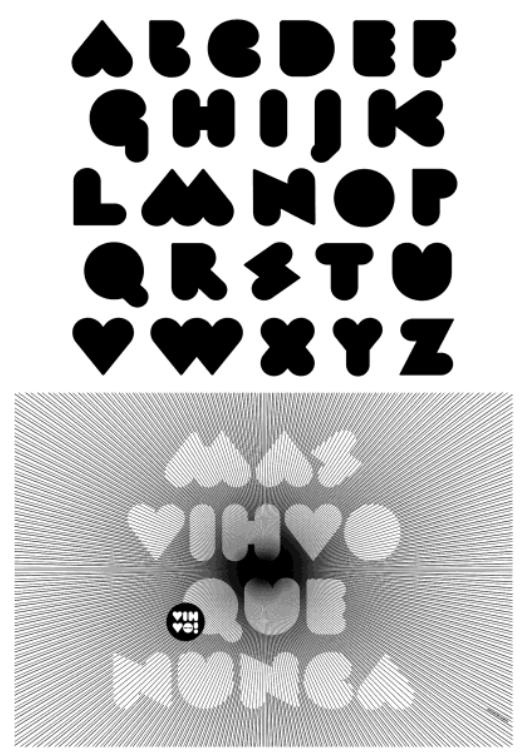

Fig. 4. VIHvo Font para VIHvo festival. Fuente: Manuel Ponce para Un mundo feliz, 2010.

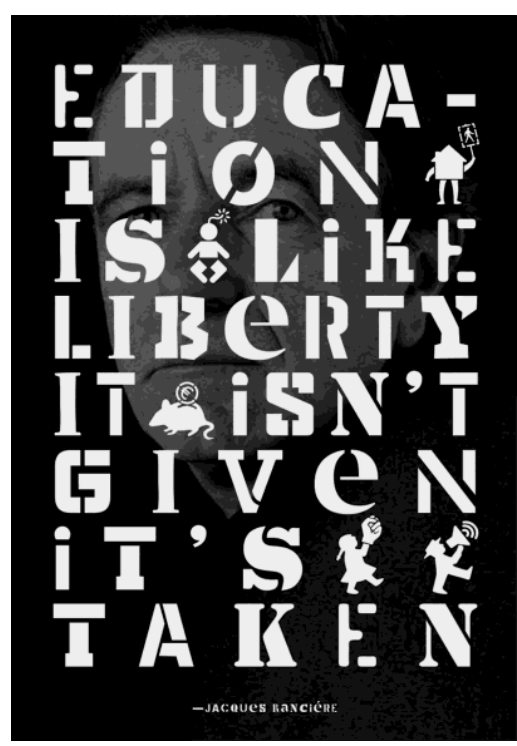

Fig. 5. Stencil Mix elaborada para Crit-icon Project. Fuente: Manuel Ponce para Un mundo feliz, 2014. 
Sus diseños son fruto de un modelo que navega entre la autorrealización y el atrevimiento. Diseños forzados-para-la-utopía, sin una orientación propia a la hora de construirse, ni criterios vinculantes universales e incuestionados. Reconstruyen signos e iconos polivalentes y sin rumbo seguro. El diseño activista de UMF sigue la filosofía de la praxis, una filosofía que se muda en política, economía, estética y ética. Es vehículo para un lenguaje crítico que interpreta e interpela a la realidad; el lenguaje es una interpretación integradora del mundo y por eso no se puede suplantar por nada, el mundo es siempre un mundo comentado y definido en el lenguaje. Se mueven en una tradición crítica donde la tipografía es una mensajera del lenguaje, estética y conceptualmente es dependiente de la palabra, y como experimento poético y forma visual crítica adquiere carácter siguiendo el camino iniciado en los poemas de Mallarmé (Drucker, 1994) y los experimentos de Marinetti y el futurismo, donde las palabras se liberan explosivamente de la composición tipográfica y sus convenciones (Heller, 2002).

Sin embargo, el aspecto político que más interesa a UMF retoma el Dadaísmo y su tipografía simbólica, provocativa y anti-estética. Según Ducker (1994) su intención es destruir la cultura racional a través del absurdo y el caos. Otro aspecto influyente del Dadá es el uso que hace de la apropiación, la subversión y la descontextualización de las formas culturales existentes. UMF utiliza estos métodos porque siguen teniendo la capacidad implícita de generar una continua crítica política.

El lenguaje y su visualización tipográfica tienen un potencial activista único y su radicalidad parte del propio sistema al que critica. Que la tipografía es una cuestión política ha sido evidente a lo largo de la historia con la imposición del abecedario romano, el diseño de las distintas tipologías e incluso con la aceptación de las normas y su crítica. Cuando Jan Tschichold propone la Nueva Tipografía está cuestionando las normas de legibilidad, construcción y percepción del alfabeto y su disposición en la página. De igual forma, cuando Josef Müller-Brockman se convierte en el impulsor de la retícula y el orden está planteando un dilema político, el orden como sistema de control, la retícula como el paradigma del capitalismo.

Otro referente esencial se sitúa a principios de 1990 cuando tiene lugar un resurgimiento de la libertad en el diseño gráfico que plantea el uso libre de la tipografía y su expresividad. La razón de este impulso es el acceso de los diseñadores a la tecnología y la tipografía digital, así como la influencia de las teorías post-estructuralistas y el desarrollo del deconstructivismo o posmodernismo. Una teoría crítica y disruptiva que se enfrenta al Modernismo. La tipografía deconstructiva o posmoderna más que un movimiento es una estrategia que defiende la exploración, la diversidad formal y cultural, la mezcla, el significado intertextual y la libre interpretación del texto. Es importante destacar que esta aportación deconstructiva, dialógica y plural no es utilizada para un fin político. De hecho muchas de estas prácticas se sitúan en un territorio acotado por la meta-crítica al propio sistema del diseño, o sus resultados darán lugar a una nueva tendencia estilística que se enseña en las escuelas de diseño - Cranbrook Academy - y sirve de apoyo al consumo interno - Emigre: revista de cultura del diseño y fundición tipográfica digital — y al consumo externo — Fuse, de Neville Brody y RayGun, de David Carson-. Aunque sólo algunos diseñadores como Jonathan Barnbrook (2007) y sus Virus Fonts 


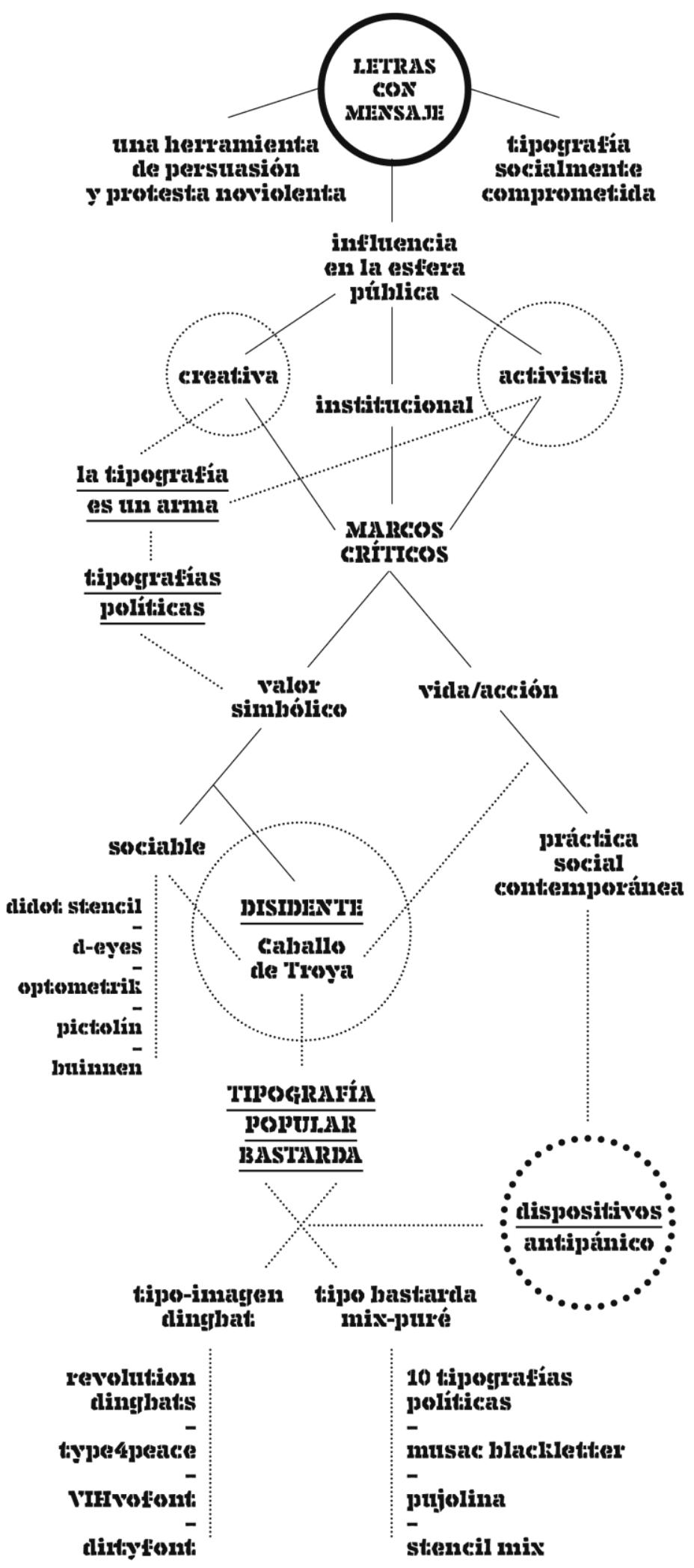

Fig. 6. Letras con mensaje. Fuente: Un mundo feliz, 2015). tomarán un camino radical de denuncia en sus investigaciones tipográficas. En España, UMF toma nota de este proceso y propone un compromiso directo entre mensaje y tipografía [Fig. 6].

\section{Fuentes como bocetos}

Las propuestas de UMF no vienen marcadas por unos objetivos precisos, sino que provocan una intencionalidad hacia las formas de implicación y cambio. El colectivo ejercita la apropiación eventual y el uso de cualquier recurso que caiga en sus manos. Les interesa el diseño colaborativo, la participación y el bajo presupuesto, «utilizando criterios del código abierto con la intención que puedan difundirse, replicarse, evolucionar» (Todoporlapraxis, 2014) de forma positiva. Para UMF teoría y práctica son inseparables, y la tipografía se articula siempre desde la praxis. Esto conlleva inevitablemente que algunas de sus propuestas fracasen. Sin embargo, piensan que cada nuevo intento forma parte del ejercicio de la comunicación abierta.

Los términos boceto $\mathrm{y}$ bosquejo presentan un significado adecuado para definir muchas de estas prácticas gráficas activistas. Una imagen activista es un boceto, una representación sin terminar de 
la revolución. Se realiza para ayudar a realizar posteriormente una imagen más acabada. Es una versión en bruto de la utopía, algo no terminado, no perfeccionado, no concluido. La disidencia creativa necesita un grado de indefinición para que su potencia sea mayor. La tipografías activistas están destinadas a la acción, funcionan como algo repentino, su puesta en práctica acontece en el momento inesperado. Por esa razón, si el diseño está acabado se convierte en una obra para el goce estético, paraliza, relaja, encanta y a la vez adormece. Por ello, es mejor que los mensajes se construyan con retazos e intentos a que se perciban como algo acabado, es decir, muerto. La tipografía desobediente es un boceto del futuro y se expresa con palabras disidentes activas.

\section{Congruencia tipográfica}

Las propuestas de UMF parten de la necesidad de promover un diseño tipográfico no demasiado estructurado que propicie el desarrollo propio pero sin olvidar el comunitario. Y esto es posible favoreciendo el uso de la tipografía como un proceso vital consciente que parte del individuo y se proyecta hacia la comunidad a un nivel de acción simbólica. Para cambiar las condiciones opresivas de la tipografía tradicional y su uso es necesario ganar autonomía a través del diseño. Tener ideas propias, independientes de las dominantes. Considerar auténtica la realidad vivida sin tener que recurrir a los valores de moda en el momento. Esta congruencia tipográfica o consciencia crítica del diseño se debe evidenciar en el tiempo, porque como afirma Raquel Pelta, «aunque tienen una consciente voluntad anti-estilo, es indudable que sus gestos les delatan y sus trabajos son de autor, en el sentido de que siempre transparentan un modo de hacer particular» (Pelta, 2003: 31).

\section{Ética/estética de la sencillez}

Las palabras e imágenes que distribuye UMF son fáciles de descifrar. Pertenecen a un código de comunicación muy directo. En general tratan de no ser exclusivas, provocando una duda, una sonrisa o un guiño en el espectador, provocan y a la vez se convierten en cómplices. Y lo más importante, están pensadas para la calle. El activismo visual trabaja con lo familiar. Trata de crear sorpresas y descubrir lo inesperado, pero siempre desde lo conocido, para que el efecto sea mayor. Según el activista Saul Alinsky (2012) no debemos salir del campo de experiencias de la gente y UMF se ha propuesto aplicar estas ideas a la tipografía. Su hipótesis aplicada a lo que denominan tipografías políticas dice lo siguiente:

[...] para generar nuevos sentidos gráficos y conceptuales no es necesario transformar un todo, en este caso un alfabeto. Cambiar algunos de sus elementos integrantes nos permite obtener otra visión de ese conjunto. Por otro lado, al mantener gran parte de los elementos redundantes, podemos reconocer el sistema como algo familiar (Díaz y Martínez, 2004: 78).

Este modelo de pensamiento-acción les permite experimentar nuevas formas que van desde la utilización expresiva a un uso más conceptual, enfatizando los detalles más visuales de la palabra y haciendo que interactúe la percepción y la producción simbólica. Esto lo consiguen explorando lo 
accidental del detalle constructivo como un elemento que re-ordena el abecedario y produce un efecto trasgresor de la fuente manipulada y potencia una lectura alternativa de los mensajes. UMF hace un uso de la tipografía destacando sus valores no-neutrales y más interpretativos con la intención de trasgredir su espíritu formal. La finalidad es contribuir a una nueva experiencia visual que enriquezca lo textual. Una relación integradora del texto, su expresión conceptual y su carácter visual. Y con esta interacción de los elementos formales y verbales aportar una interpretación más sugerente. La reelaboración tipográfica que propone UMF parte de las letras, elementos mínimos del lenguaje, como base potencial de la creatividad. Este planteamiento evoca el letrismo y las ideas de Kurt Schwitters quien sugiere que la materia de la poesía es la letra y el abecedario, no la palabra. La tipografía es un recurso interesante a la hora de expresar contenidos críticos. Por esa razón, los diseños tipográficos de UMF no buscan la originalidad, sino que parten de referentes conocidos que posteriormente son manipulados con una finalidad expresiva y comunicativa.

\section{Tipografía como imagen}

Según Mircea Eliade (1955) «La existencia más mediocre está plagada de símbolos. El hombre más realista vive de imágenes [...] los símbolos pueden cambiar de aspecto; su función permanece la misma. Se trata sólo de descubrir sus nuevas máscaras». Es evidente que las imágenes y las palabras son maneras de transmitir conceptos o ideas. Y esa es la premisa del trabajo de UMF, hacer de la tipografía un transmisor fuerte. La tipografía comunica contextos, situaciones, recuerdos; un uso adecuado de las fuentes tipográficas aporta un timbre de voz adecuado a un mensaje. UMF utiliza las letras tanto para formar palabras como para crear imágenes. En sus proyectos combinan estos dos usos transmitiendo, mediante las letras, un mensaje verbal y otro icónico. Su método principal propone trabajar con tipografías ya existentes, respetando su trazado o modificándolas y en algunos casos diseñar nuevos tipos ex profeso. La palabra, por sí misma, ya es capaz de transmitir información suficiente; sin embargo, la forma y distribución de las letras aplicada en el diseño aportan mayor impacto visual y dan carácter al mensaje. Desde el punto de vista formal y conceptual la tipografía habla por si misma, por esa razón UMF selecciona cuidadosamente las palabras y les aplica el estilo adecuado en cada ocasión.

La poesía visual, hermana del diseño gráfico, es en la actualidad una de las bases conceptuales del diseño gráfico posmoderno. La poesía visual aporta al diseño una retórica o reglas de alteración (adición, supresión, permutación y sustitución) que permiten dar un salto de nivel si se quiere construir usos formales y conceptuales más intensos. UMF utiliza muchos de estos recursos para la construcción de mensajes gráficos. Una retórica (reglas de alteración) y gramática (reglas de formación) nacidas de la influencia de la poesía visual. Ejercicios de estilo y experimentos conceptuales-formales cuyo resultado se aplica a la creación de imágenes útiles para la comunicación activista. 


\section{Tipografías políticas}

Uno de los proyectos más definitorios del colectivo es Tipografías Políticas. Un ejercicio de manipulación tipográfica basado en la experiencia de que a veces no hay tiempo para crear imágenes singulares; entonces, basta con hacer un uso adecuado de la tipografía. Ésta es la idea, una palabra es una imagen. Según el diseñador Gérard París-Clavel (citado en Rodríguez, 2002: 38) «las palabras hacen la imagen», son elementos plásticos y portadores de significado. El activismo gráfico nace en el marco de una cultura de consumo y cuestiona su engranaje de seducción. Se sabe que como diseñadores profesionales muchas veces trabajamos generando formas sin un sentido o discurso realmente significativo. Esto es fruto de lo que Neil Leach (2001: 15) denomina una «sobredosis de la estética», «estética de la saturación»o «estética de la embriaguez».

Este proyecto nació con la intención de activar las formas tipográficas estándar. Así, Tipografías Políticas se proponía como un ejercicio de análisis y contextualización, de busca de significados y de intercambio de mensajes. La apariencia superficial del alfabeto se utiliza como puerta de acceso a una lectura más profunda proponiendo imágenes como actos de pensamiento, y la tipografía como su transmisor radical. Su tesis principal era que «la palabra es una herramienta de diseño» donde la tipografía representa un medio, no un fin. Partiendo de este hecho, se intentó demostrar que los diseñadores no-tipógrafos podían hacer una aportación sustancial al lenguaje tipográfico desde la perspectiva del mensaje. Otra idea importante fue considerar que «el todo es más que la suma de las partes». Esta hipótesis de trabajo explica por qué para generar nuevos sentidos gráficos y conceptuales no es necesario transformar un todo, en este caso un alfabeto. Cambiando sólo algunos de sus elementos integrantes se podía obtener otra visión de ese conjunto. Por otro lado, al mantener gran parte de los elementos redundantes, se seguía reconociendo el sistema como algo familiar y permitía experimentar nuevas formas que iban desde la utilización expresiva a un uso más conceptual. La reelaboración de estas tipografías parte de las letras, elementos mínimos del lenguaje, como base potencial de la creatividad. Este planteamiento evocaba el letrismo y algunas ideas sobre el tratamiento tipográfico ejemplificado en la «Futuriste Typeface» de Alessandrini, la marca «I love NY» de Milton Glasser o el proyecto de diseño y poesía concreta «Watching Words Move» de Browjohn, Chermayeff y Geismar. Otra referencia ineludible fueron las tipografías Bastard, False Idol y Patriot de Jonathan Barnbrook.

\section{Pictopía: Dingbats y pictomontajes}

UMF destaca por el uso de los pictogramas y los dingbats como herramientas de gran potencia gráfica y comunicativa por su capacidad para «ofrecer lo principal». Según Félix Beltrán (2011), UMF son representantes destacados «del movimiento de los pictos»y «han experimentado hasta convertir los pictos en un vocabulario extraordinario de amplias posibilidades, donde la secuencia y las relaciones establecidas entre ellos se afirman como recursos para la comunicación más rápida y precisa». La principal razón para utilizar este lenguaje de imágenes, es porque 
[...] es un medio privilegiado para entendernos, visualizar opiniones y deseos. Un lenguaje que rompe las barreras del idioma y permite un mayor desarrollo de la cultura, el intercambio social y la economía. Las imágenes se convierten en formas esenciales de comunicación, allí donde la palabra y la letra no alcanzan (Díaz y Martínez 2011).

La pictografía se identifica con una forma de escritura donde las ideas son transmitidas a través de dibujos tratados de forma sintética, como sucede en la escritura cuneiforme y en los jeroglíficos. UMF retoma la filosofía de los modelos de comunicación ancestrales y recupera elementos del lenguaje mnemónico para el activismo visual. Lo bueno de estos sistemas de escritura es que «mezclan de forma libre signos, símbolos y pictografías para sintetizar ideas, pensamientos y sucesos. Dichos recursos icónicos de representación permiten que diferentes grupos sociales puedan grabar, objetivar y organizar sus actividades e ideas, y así, evitar su pérdida» (Díaz y Martínez 2011).
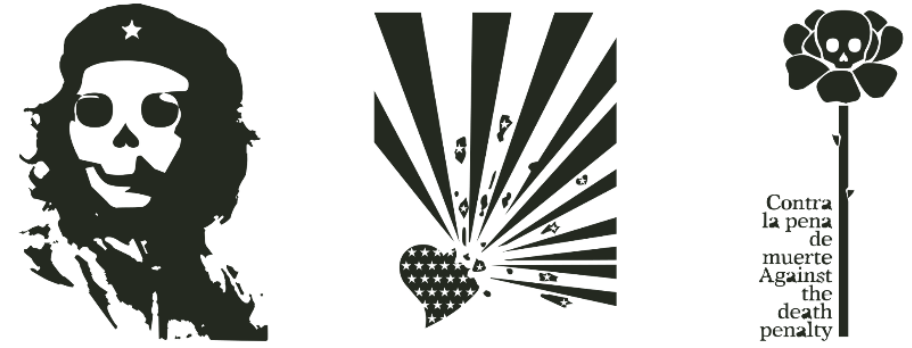

REVOLUTION DB1 65 DINGBATS

TRUETYPE FONT

IBERDERS

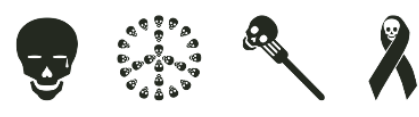

PRESIDENT\&GQ
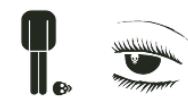

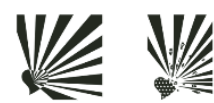
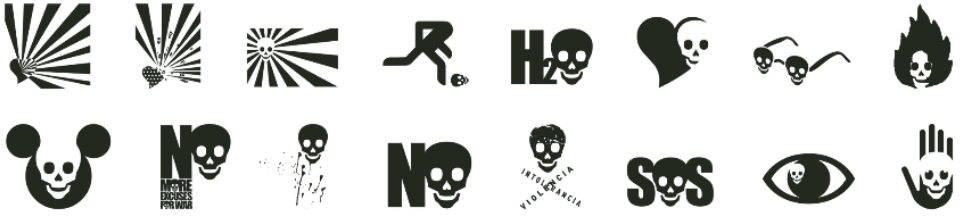

舟
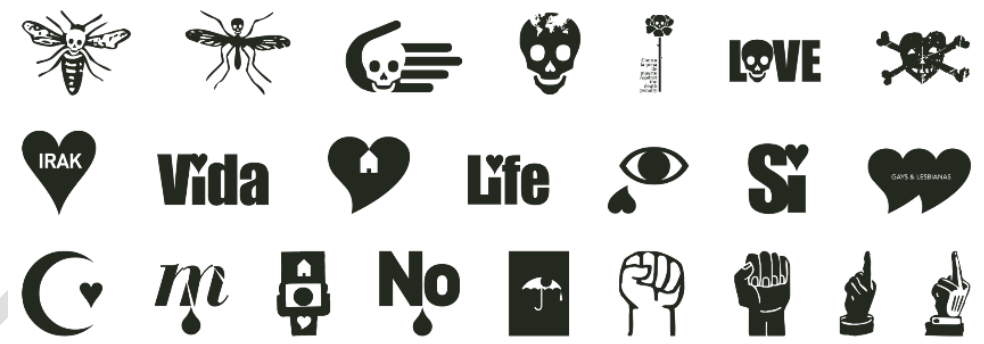

No

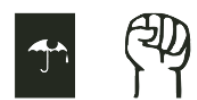

(1)

of itio
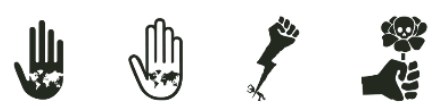

$\bigcap_{\text {EE }}$
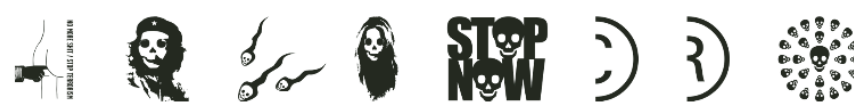

Fig. 7. Dingbats. Un mundo feliz

UMF se plantea la recreación de sistemas pictográficos múltiples utilizando un método que permite expresar ideas críticas y dialécticas de forma consciente al servicio de la agitación política. El método consiste en la yuxtaposición de pares binarios de signos gráficos y lingüísticos que se cruzan aportando nuevos sentidos. El poder crítico del código manipulado — significante/significado- aporta una fuerza semántica que permite poner en cuestión los signos. Esta forma se basa en los trabajos de John Heartfield e interpreta su técnica del fotomontaje hacia lo que podemos denominar pictomontaje. Lo más interesante del trabajo es que funciona como un emblema moderno, es decir, las imágenes siempre van acompañadas de un título y subtítulo que provocan que cada imagen funcione «como una forma de instrucción moral y política» (BuckMorss, 1995). Por otro lado, un dato esencial es que los fotomontajes de Heartfield no se pueden tomar como objetos estéticos, sino como imágenes para leer en un sentido profundamente 
político (Burger, 1984). Siguiendo las lecciones de Heartfield, el principio de construcción de los pictomontajes o dingbats es el montaje de varios elementos irreconciliados que no buscan fusionarse de forma armónica sino activa.

\section{Un lenguaje ready-made (copy-paste)}

Tipomontaje, pictomontaje, ensamblaje picto-tipográfico, picto-poema protesta, etc. El trabajo de UMF parte de una tradición que enlaza con el collage, el assemblage y el fotomontaje. Comparte con ellos ese «principio de la interrupción» de Brecht del que habla Walter Benjamin (1975) en El autor como productor. Esta influencia del método de composición de Walter Benjamin y John Heartfield, su «método de montaje», les ha permitido aprender a expresar ideas críticas y dialécticas de forma consciente para aplicarlas a la agitación política. El impacto visual se logra yuxtaponiendo dos conceptos contrapuestos que se cruzan para dar otro significado. Es una propuesta crítica y dialéctica que se consigue expresar a través de la imagen con una intención moral y política. La idea del montaje pictográfico-tipográfico tiene una lógica tanto conceptual como técnica y toma como referencia los fotomontajes de Heartfield porque representan un tipo completamente diferente (en relación a los collages modernistas de los cubistas). No son primariamente objetos estéticos, sino imágenes para leer. Y en la actualidad

\footnotetext{
Los entornos de producción digital nos ofrecen una plataforma para crear y experimentar con nuevos criterios visuales. Esto ha permitido acortar los tradicionales procesos de diseño, potenciando la manipulación de las imágenes y de los contenidos. El copia y pega (copy-paste) es un proceso habitual de trabajo. En el ámbito de la tipografía digital se adopta este modelo deconstructivo para generar un flujo continuo de mutaciones formales (Díaz y Martínez, 2004: 78).
}

Todos los usuarios del ordenador somos tipógrafos en potencia. El diseño gráfico actual tiene un acceso a la manipulación y creación tipográfica impensable hace unas décadas. La autoedición permite autonomía y rapidez. Por otro lado, el concepto de originalidad ya no es relevante y la apropiación se ha convertido en un modo de actuar natural de nuestra época posmoderna. «La apropiación, por ejemplo, es una de esas prácticas y (los) diseñadores [...] las emplean no sólo como método de trabajo sino también como estrategia crítica mediante la que cuestionar el carácter representacional de nuestra cultura» (Pelta, 2003: 31). UMF ha manifestado desde el principio la necesidad de manipular y revisar tipografías existentes para construir mensajes a medida. Las herramientas del diseño son tomadas como recursos para la experimentación porque permiten conseguir el máximo potencial de esa unión: mensaje-imagen/concepto-imagen. Para ello siguen las reglas marcadas por Art Chantry: «roba en la oscuridad, altera significativamente y usa adecuadamente» (Pelta, 2003). Mientras que para el modelo más tradicional «la tipografía es el arte de diseñar letras y componer textos de tal modo que puedan leerse de un modo fácil, eficaz y agradable» (Kunz, 2004), para UMF lo importante es la potencia radical del mensaje. Por esa razón, manipulan las tipografías clásicas y familiares, porque al ser ya conocidas les permiten aportar mayor expresividad y definir nuevos contextos significantes. 
172 Tropelías. Revista de Teoría de la Literatura y Literatura Comparada, 26 (2016)

José Gabriel Martínez García y Sonia María Díaz Jiménez

\section{Diseño popular bastardo}

El activismo cultural desde el punto de vista de UMF debe ser co-constructor de discurso, de un significado independiente (autonomía), alternativo (diferencia, alteridad) y generador de comportamientos libres (no de consumo). UMF entiende su trabajo como un dispositivo de emergencia $y$ antipánico en la era de internet. Poder combinar, mezclar, remezclar o yuxtaponer ideas, imágenes, palabras y símbolos que puedan ser accesibles a todo el que los quiera utilizar. Por esta razón, las experiencias de UMF se proponen como ejemplos de funcionamiento del diseño en la encrucijada del saber social y la acción en la esfera pública. Las imágenes de UMF tienen vocación de ser compartidas y reinterpretadas. Se han hecho públicas en distintas ocasiones y con formatos muy diferentes. A este modo de trabajar lo denominan «Karaoke Revolution Project». La agitación gráfica empieza en el espacio privado pero se expande al espacio público. Por eso, la idea fundamental del proyecto era visualizar posibles prácticas culturales y sociales. UMF señala que partiendo del espacio público e institucional (museo, centro de arte o galería) se pueden crear otras formas básicas de «culturalidad» que fluyan hacia la calle. Además, tanto el espacio privado como el público son entornos propicios para un posicionamiento estético singular y para el libre pensamiento. Con este planteamiento empezaron a diseminar sus propuestas gráficas utilizando el formato $\mathrm{CD}$ en su proyecto Revolution dingbats \& motiondingbats donde incluían ciento cuarenta y seis iconos o pictogramas de libre uso que regalaban a la gente para que los utilizara con fines no comerciales. Después publican Pictopía, un libro que contiene cuatrocientos pictogramas y doscientas micropelículas también de libre uso. En 2014 editan Crit-icon Stencil Book, un kit de plantillas en formato A5 y la fuente Stencil Mix, que se regalan para que la gente los utilice interviniendo espacios públicos y privados.

El «Karaoke Revolution Project» se basa en la interpretación libre de un lenguaje de patrones («a pattern language») de Christopher Alexander. Un patrón de diseño es una solución a un problema de diseño que se puede aplicar de forma reiterada en distintas circunstancias. Según Christopher (1977) «cada patrón describe un problema que ocurre infinidad de veces [...], así como la solución al mismo, de tal modo que podemos utilizar esta solución un millón de veces más adelante sin tener que volver a pensarla otra vez». Siguiendo este modelo, UMF recopila elementos reutilizables formulando un vocabulario común para el activismo visual.

\section{Humor, fakes y tipografía}

El activismo asociativo pone su foco en el arte y el diseño. El activismo especulativo va más allá y explora nuevas aplicaciones basadas en las ciencias y las nuevas tecnologías. El activismo crítico busca cambiar las condiciones dadas y la función social del propio activismo y sus formas. Según Malpass (2012: 4) estos diseños, sus técnicas y prácticas funcionan como formas de diseño satírico que responden a diferentes necesidades. La sátira es un recurso que sirve para expresar indignación hacia alguien o alguna cosa; su propósito puede ser moralizador, lúdico o burlesco. En la sátira se ponen de manifiesto los abusos y las deficiencias mediante el ridículo, la farsa, la ironía, el sarcasmo, 
la parodia, la burla, la exageración, el juego, las comparaciones, las yuxtaposiciones, la analogía, la denuncia y otros muchos métodos. En este sentido se puede decir que la sátira es una herramienta militante y comprometida, porque aunque tenga un fuerte componente lúdico, su propósito principal es atacar a una realidad que se desaprueba con el arma de la inteligencia. Es una formalización crítica ideada para provocar una mejora de la sociedad. Tanto los artistas como los diseñadores «críticos» se plantean incorporar su trabajo dentro de una práctica general que supere las fronteras de la institución artística o el diseño comercial. Su posición se propone como una práctica democrática, enfocada al debate y superadora de la creatividad más personal. Estos modelos se mueven por una voluntaria insubordinación crítica y plantea una alternativa contra la producción capitalista donde está integrada (Thackara, 2000: 22).

Según la tesis de Søren Kierkegaard (Frazier, 2007) «la pura ironía es una postura incoherente y por tanto irrealizable», porque es negativa y destructiva. UMF propone una ironía como una crítica ética que dispara provocando el pensamiento crítico. El diseño crítico utiliza la ironía como medio, no como un fin. La ironía es un modo de poner en cuestión las cosas, de sacar a la luz los problemas. Su valor positivo está en su capacidad de provocar un cambio, primero mental y después físico. La ironía que utilizan en sus palabras e imágenes es esencialmente práctica, porque «el ironista se encuentra siempre en disputa con lo real» (Peña, 2014).

Para UMF el uso de la tipografía puede ayudar a «diseñar maneras de ver aquello que no se ve» (Tackara, 2000). Y eso mismo sucede cuando se mezcla con el humor. Porque, como defiende Saul Alinsky, el humor es esencial para el éxito de una táctica, utilizar la sátira y el ridículo son armas muy poderosas. El humor es «la facultad mental de descubrir, expresar o apreciar elementos disparatados, absurdos o incongruentes en ideas, situaciones, eventos o actos...» (Diccionario Merriam - Webster). Otro recurso de crítica y denuncia muy utilizado por UMF son las parodias o falsos logos —fakes-. A través de estas intervenciones «extraen elementos de su contexto habitual y se apropian de signos protegidos por el copyright: marcas conocidas e imágenes comerciales que toman prestadas y son el símbolo de una cultura corporativa que lo está invadiendo todo» (Pelta, 2003: 32). Especialmente son interesantes las manipulaciones verbales que realizan mediante sutiles juegos de palabras y cambios de letras. Ésta es su manera activista de contestar al diseño original.

\section{Autoedición crítica, del samizdat al fanzine-panfleto}

El uso de la tipografía como herramienta comprometida con las ideas no es nada nuevo. La ideología y la autonomía han marcado una forma de actuar independiente del mercado y de las expectativas de cada época. El discurso crítico con la sociedad, ya sea capitalista, socialista o comunista, es una tónica general de los creadores que quieren desmarcarse y proponer alternativas. La autoedición aporta libertad, es un marco ético favorable para la investigación-experimentaciónproducción-diseminación-reflexión. Permite conectar lo personal y lo colectivo, y construye significado a través de la experimentación tipográfica (formato, imagen, palabra). 
Una referencia en el trabajo de UMF es la autoedición ética y disidente promovida por la tradición samizdat, un término ruso que aparece como el opuesto a las publicaciones permitidas por el estado o gosizdat. El samizdat es una práctica disidente que se transmite en privado y permite la circulación de material (literatura, documentación histórica, notas y comentarios críticos) no sometido a la censura institucional. Las formas que presenta son múltiples, con tendencia a la autoproducción manual o de tiradas cortas y con modos de distribución autónomos y personales. Frente a otros modelos, el samizdat es un procedimiento práctico e ideológico. Según Stewart Home este término es aplicable a una larga tradición vanguardista como el Letrismo, Situacionismo y Fluxus porque están marcados por los mismos valores: lo colectivo, la auto-organización y el disentimiento (Home, 2002). Para Steven Heller estas cualidades de las publicaciones independientes son la expresión gráfica de los movimientos vanguardistas (Heller, 2003). Su función es visualizar una posición ideológica, cultural y política al margen del mercado del entretenimiento, con la finalidad de provocar un cambio social. La idea es sencilla, toda publicación activista pretende hacer visible y comunicar una posición cultural y política. Los ejemplos más interesantes aparecen con el Futurismo y Dadá. Y las herramientas que utilizan son realmente transgresoras. El collage y el assemblage permiten expropiar y recontextualizar imágenes y palabras de la cultura popular comercial. Es una forma sencilla y rápida de cuestionar la realidad comprometiéndola. Sin embargo, lo más interesante de estas prácticas es su carácter efímero y su función anti-plástica. Son agresiones visuales que trastocan muestra percepción de las cosas. Otro movimiento que retomará esta metodología es el punk. El punk es ejemplar en la utilización de las imágenes anti-elitistas de baja resolución y su diseminación a través de la fotocopia. Esta nueva forma de auto-publicación samizdat emergente tendrá el formato «zine». Según Steven Perkins (1992), los Punk zines sacan a la luz la cultura rebelde, antipática e insurrecta de la juventud de clase obrera inglesa. Los zines o fanzines, en su sentido más genuino, representan un formato de revista anticomercial, amateur o anti-profesional donde es el mismo autor quien produce, publica y distribuye (Duncombe, 1997).

Samizdat y zine pertenecen a la cultura del DIY (Do It Yourself) y son publicaciones más éticas que estéticas. Representan una práctica política que parte de lo auténtico. Son un acto de creación e intercambio que promueve la cultura propia, una visión y unos valores alternativos al statu quo. En resumen, son un acto político que se hace explícito gracias a la tipografía liberada y el panfleto (Thoburn, 2014: 83-85). Una interpretación actual del grito «la palabra al poder» de mayo del 68 que mantiene viva la filosofía de los «poemas-panfleto», los «poemas-carteles» (Badenes, 2006: 158) y el placer de retomar las pintadas-poema callejeras que ejercita Neorrabioso (Batania, 2013).

\section{Neosamizdat: una agitación política, cultural y gratuita}

La publicación Bastard Art Review es un exponente del neosamizdat, una ejercicio de disidencia, autogestión, autoedición y autoproducción que enfatiza el amateurismo. El neosamizdat es principalmente una sensibilidad constructiva de una nueva subjetividad social que se desmarca y 
promueve «un desorden aún desconocido» (Home, 2002). Bastard Art Review nació como una propuesta crítica frente al periodismo actual que se salta su propio código deontológico, no respeta la verdad y desdibuja el principio de la libertad de investigar y de difundir con honestidad la información y la libertad del comentario y la crítica.

La autoedición tiene una función social directa. Permite intercambiar y transmitir ideas de forma independiente y crear una comunidad alternativa a los canales institucionalizados. El intercambio es un proceso de acercamiento y un diálogo. Para UMF la autoproducción y la autodistribución fomentan el encuentro, permiten la relación directa y casual. Se rompe la estructura jerárquica que impone lo institucional y lo académico. UMF propone la comunicación como una iniciativa radical. Es una práctica de intercambio libre que involucra de alguna manera a todos los participantes. Un neosamizdat que se formaliza en una revista (Bastard Art Review), zines y poster-zines (Bold), postales, folletos y libros (Boldbooks), plantillas (Crit-icon Stencil), pegatinas, chapas, calcomanías, carteles y tipografías/dingbats. Otro aspecto interesante es la utilización de Internet. La ubicuidad de este medio ha permitido una comunicación global y rápida, y que las prácticas colaborativas sean más habituales y fructíferas. El modelo de código abierto y la expansión de la cultura libre han proliferado de forma natural en este medio. La posibilidad de crear y distribuir cultura utilizando las herramientas digitales parece algo inimaginable hace unos años. Sin embargo, no utilizar blogs, sitios web o Facebook parecería visualizar que no estamos conectados. Vivimos la época dorada de las comunidades virtuales y del intercambio global. El eslogan feminista «lo personal es político» se ha hecho realidad gracias a los blogs y a las galerías de imágenes donde muchas personas pueden acceder a leer y mirar estos diarios digitales personales que se hacen públicos con la intención de compartir información, sentimientos y experiencias.

Al igual que señalara Stewart Home (2002: 33) en su libro Asalto a la cultura, la intención del colectivo UMF ha sido desde el principio tratar de descubrir y aprender de un montón de agitadores que ha habido a lo largo de la historia. UMF se sitúa en la tradición utópica que desde siempre ha buscado una integración de todas las actividades humanas en orden a eliminar la separación de las cuestiones sociales, políticas y culturales. El colectivo es heredero «bastardo» del movimiento «utopista» basado en la búsqueda y demostración de un espíritu libre (Sade, Fourier, Lautremont, Morris, Jarry, el Futurismo, Dadá, el Surrealismo, el Letrismo, los situacionistas, Fluxus, el Mail-art, los provos holandeses, los motherfuckers, King Mob, los yippies, el punk, el Black Power, Class War, el Neoísmo y las diferentes modas anarquistas y underground contemporáneas). En sus proyectos «intentan politizar la cultura y transformar lo cotidiano» (Collins, 1992, citado en Home, 2002: 35). Con sus publicaciones autoeditadas mantienen el espíritu de revistas como Smile, Here and Now, Edinburgh Review, la situacionista SPUR o el boletín de la Internacional Letrista (IL) Potlatch que «hace referencia a las sociedades precomerciales que funcionan según el principio del regalo en vez del principio del intercambio económico, por esa razón era gratuito» (Debord, cit. en Home, 2002: 79). Esa idea de divulgar material de forma gratuita aporta siempre un valor utópico de la práctica artística de diseño como un artefacto cultural abierto y consciente. En ese mismo sentido, la referencia a «la 
estética fluxus, de una simplicidad sin pretensiones [es] implícitamente un asalto a la cultura seria» (Home, 2002: 119). Porque para UMF la comunicación creativa es principalmente social —no estética-, es decir, tiene un enfoque radical-funcional (Maciunas, cit. en Home, 2002: 123). Por ejemplo, la fuente VIHvo Font nació como una iniciativa autorreflexiva «enfocada sobre las acciones expresivas de los miembros de la colectividad» (Chihu y López, 2007). Y si bien es un proyecto personal, su función fue la de ser una tipografía diseminada y compartida para conseguir mayor visibilidad del colectivo con VIH.

\section{CONCLUSIÓN}

\section{Las formas de la insolencia tipográfica}

En este texto hemos intentado descubrir el valor social y cultural de la palabra como arma (Goldman, 2010) en la concepción activista de la comunicación. Que la protesta nunca es estética sino emocional (Flood y Grindon, 2014: 12) y su valor es el de la lucha. Por ello, percibimos que las tipografías desobedientes no aspiran a tener visibilidad cultural y, sin embargo, la consiguen si su entorno es proclive al cambio, reflejan la estética y los gustos de su tiempo, retoman formas y herencias simbólicas históricas y son conscientes de su valor como herramientas de comunicación directa.

Los diseñadores necesitan nuevos espacios y contextos para experimentar, y el espacio público y sus causas son un buen reclamo para sus actividades. Toda insolencia induce a salirse de las normas, es un insulto a la apariencia, un desafío a las costumbres. Por eso, la «insolencia libertaria» se vale de la tipografía para desafiar a la ficción social. La tipografía activista se manifiesta como una herramienta de transgresión, apropiación y subversión. Es forzosamente militante y desarrolla una cultura visual alternativa que trata de reinsertarse en las diferentes esferas de manifestación pública.

En resumen, la tipografía activista se puede explicar teniendo en cuenta tres parámetros fundamentales: una teoría crítica que permite la posibilidad de explorar el diseño como una manifestación idealista, social y subversiva; una ética activista e insolente que desde la autonomía se pone al servicio de las causas; y una estética activa de gran potencia emocional que sirve de herramienta comunicativa.

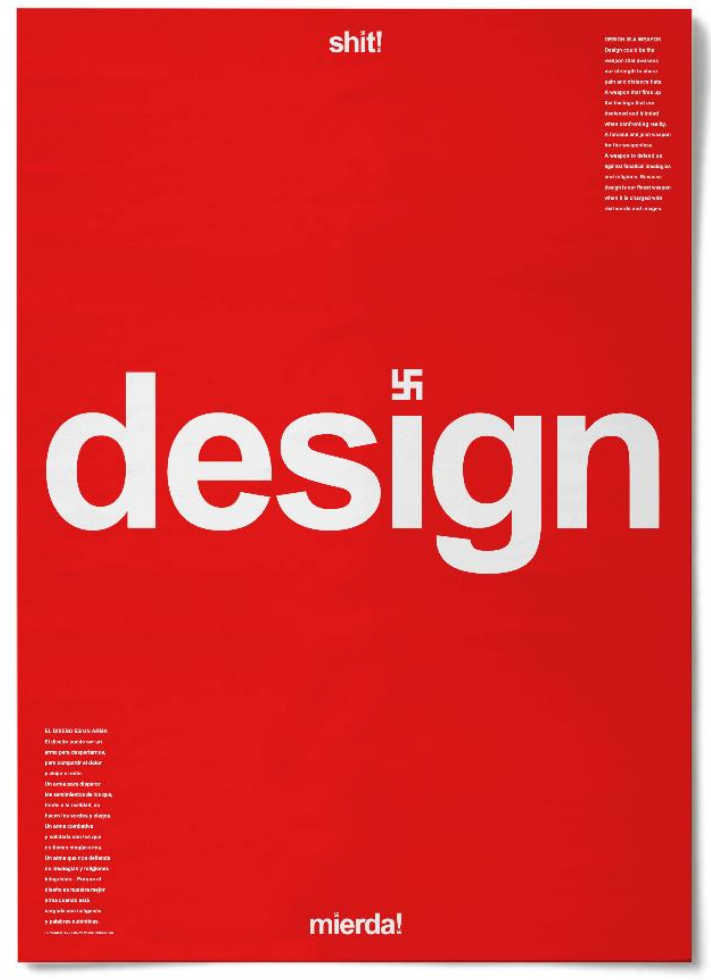

Fig. 8. Fuente Arial Symbol. Un mundo feliz 


\section{Bibliografía}

AleXAndre, C. - Ishikawa, S. - Silverstein, M. (1977): A Pattern Language: Towns-BuildingConstruction. New York, Oxford University Press.

AlinsKY, S. (2012): Tratado para radicales: manual para revolucionarios pragmáticos. Madrid, Traficantes de Sueños.

AtTAl, J. (1995): Ensayo sobre la economía política de la música, México, Siglo XXI.

BACHelard, G. (1964): The Poetics of Space. New York, Orion.

BADENES SAlAZAR, P. (2006): La estética en las barricadas: mayo del 68 y la creación artística. Castellón, Universidad Jaume I.

BAÑUelos CAPISTRÁn, J. (2008): Fotomontaje. Madrid, Cátedra.

BARnBrooK, J. (2007): Barnbrook Bible. The Graphic Design of Jonathan Barnbrook. New York, Rizzoli.

Batania (2013): Neorrabioso. Poemas y pintadas. Palma de Mallorca, La Baragaña.

BAUDRILLARD, J. (1994): Las estrategias fatales. Barcelona, Anagrama.

BELTRÁn, F. (2011): «Nuevas perspectivas para los tipos», en Sonia DíAZ y Gabriel MARTínEZ, eds. Imagomundi. Barcelona, Promopress.

BENJAMIN, W. (1975): El autor como productor. Madrid, Taurus.

Bey, H. (1991): T.A.Z.: The Contemporary Autonomous Zone, Ontolgical Anarchy, Poetic Terrorism. Brooklyn, Autonomedia.

Boon, M. (2013): In Praise of Copying. Cambridge, Harvard University Press.

BRown, G. - JeNNY, P. (2009): «Space for Emotion in the Spaces of Activism», Emotion, Space and Society 2/1, pp. 24-35.

Buck-Mors, S. (1995): Dialéctica de la mirada. Walter Benjamin y el proyecto de los pasajes. Madrid, Visor.

BÜRgER, P. (1984): Theory of the Avant-Garde. Minneapolis, University of Minnesota

CASTAÑAR, J. (2010): Breve historia de la noviolencia. Madrid, Pentapé.

CHIHU, A. - LóPEZ, A. (2007): «La construcción de la identidad colectiva en Alberto Melucci», Polis 3/1, pp. 125-159.

DÍAZ, S. - MARTÍNEZ, G. (2004): «Spacetypografhiko. El revival copiaypega», comunicación presentada en I Congreso de Tipografía. Tipos, Tópicos, Textos y Contextos, Valencia, 25 al 27 junio, inédita. (2011): Imagomundi. Barcelona, Promopress.

Duncombe, S. (1997): Notes from Underground: Zines and the Politics of Alternative Culture. London/New York, Verso.

Dunne, A. - RABy, F. (2001), Design Noir: The Secret Life of Electronic Objects, Basel, Birkhauser, 2001.

(2014): «A Manifesto. Dunne and Raby», en http://www.dunneandraby.co.uk/content/ projects/476/0 (última consulta 7-4-2016). 
DURUS (1989): «Fotomontage, Fotogramm», en Christopher PHILLIPS, ed., Photography in the Modern Era: European Documents and Critical Writings, 1913-1940. New York, Metropolitan Museum of Art, pp. 182-185.

Escosteguy, A. (2008): «Circuitos cultura circuitos de comunicación: un protocolo analítico de la integración, la producción y la recepción», Estudios sobre las culturas contemporáneas, XIV, 27, pp. 149-167.

ELIADE, M. (1995): Imágenes y símbolos. Madrid, Taurus.

ELIASSON, O. (2012): Leer es respirar, es devenir. Barcelona, Gustavo Gili.

Fallman, D. (2008): «The Interaction Design Research Triangle of Design Practice, Design Studies, and Design Explorations», Design Issues, 24/3, pp. 4-18.

Flood, C. - GAvin, G. (2014): Disobedient Objects. London, V\&A Publishing.

FORMES VIVES (2008): «Citoyen-Graphiste», en http://www.formes-vives.org/atelier/?category/ Citoyen-graphiste (última consulta, 3-5-2016).

FRASCARA, J. (2004): Diseño gráfico para la gente: comunicaciones de masa y cambio social. Buenos Aires, Infinito.

FrAZIER, B. (2007): «Kierkegaard ante los problemas de la pura ironía», Revista Praxis Filosófica, 24, pp. 167-199; en http://www.redalyc.org/articulo.oa?id=209014643009 (última consulta, 24-102014).

Goldman, E. (2010): La palabra como arma. Buenos Aires - Madrid, Libros de Anarres - Terramar - LaMalatesta.

Fullat, O. (2002): El siglo postmoderno (1900-2001). Barcelona, Crítica.

Heller, S. (1992): «Hit and Run», en Karrie JACOBS and Steve HelleR, eds., Angry Graphics: Protest Posters of the Reagan/Bush Era. Salt Lake City, Peregrine Smith Books, pp. 2-7.

HERNÁNDEZ MUÑOZ, S. (2008): El humor como estrategia y reflexión en la publicidad española (2007 y 2008). Valencia, Universidad Politecnica de Valencia, en https://riunet.upv.es/bitstream/ handle/10251/13232/tesis\%20Silvia\%20Hernandez\%20Mu\%C3\%B1oz-.pdf?sequence=1 (última consulta, 25-6-2016).

Home, S. (2002): El asalto a la cultura: movimientos utópicos desde el letrismo a Class War. Barcelona, Virus Editorial.

JACOBI, F. (2012): Aesthetics of Resistance: An Investigation into the Performative Politics of Contemporary Activism - as Seen in 5 Events in Scandinavia and Beyond, Lund, Lunds Universitet, en https://lup.lub.lu.se/search/ws/files/5445414/3158036.pdf (última consulta, 25-62016).

Jordan, T. (2002): Activism! Direct Action, Hacktivism and the Future of Society. London, Reaktion Books.

JULIER, G. (2010): La cultura del diseño. Barcelona, Gustavo Gili.

KAtsiafiCAS, G. (2010): «Reading Signs of Change», en Dara GreEnwald and Josh MaCPheE, eds., Signs of Change. Social Movement Cultures 1960s to Now. Oakland, AK Press, pp. 19-21. 
KunZ, W. (2004): Macro y micro estética. Barcelona, Gustavo Gili.

LEACH, N. (2001): La an-estética de la arquitectura. Barcelona, Gustavo Gili.

LIPOVETSKY, G. (1986): La era del vacío: ensayos sobre el individualismo contemporáneo. Barcelona, Anagrama.

LIPPS, T. (2015): El humor y lo cómico. Barcelona, Herder.

Malpass, M. (2012): Contextualising Critical Design: Towards a Taxonomy of Critical Practice in Product Design. Nottingham, Nottigham Trent University, en http://ualresearchonline.arts.ac.uk/ 6102/1/Contextualising_critical_design.pdf (última consulta, 25-6-2016).

MeluccI, A. (1996): Challenging Codes: Collective Action in the Information Age. Cambridge, Cambridge University Press.

PAdilla, M. (2012): El kit de la lucha en internet. Madrid, Traficantes de Sueños.

PARREÑO, J. (2006): Un arte descontento. Murcia, CendeaC.

Pelta, R. (2002): «Art Chantry», Visual: Magazine de Diseño, Creatividad Gráfica y Comunicación, 97, pp. 88-96.

(2003): «Diseño y arte. Paralelismos y sincronías», en Raquel Pelta, Paco Rallo et al., Sin límites. Visiones del diseño actual. Zaragoza, Diputación de Zaragoza, pp. 19-40.

- (2004): Diseñar hoy. Barcelona, Paidós.

Peña Arroyave, A. (2014): «Søren Kierkegaard. La melancolía como fundamento de la existencia estética», Metafísica y Persona. Filosofía, Conocimiento y Vida, 12, pp. 95-143; en http://metyper.com/soren-kierkegaard-la-melancolia-como-fundamento-de-la-existencia-estetica/ (última consulta, 12-7-2015).

PERKINS, S. (1992): Approaching the '80s Zine Scene, en http://www.zinebook.com/resource/ perkins.html (última consulta, 24-6-2016).

READ, H. (1982): Educación por el arte. Barcelona, Paidós.

REED, C. (2000): «Posmodernidad y el arte de la identidad», en Nikos STANGOS, Conceptos del arte moderno. Barcelona, Destino.

RoDríGUEZ, L. (2002): «Diseño y sociedad, aproximaciones. Definir el diseño», en Stella Maris RoDIO, ed., Diseño: teoría y reflexión. Buenos Aires, Librería Técnica CP67, pp. 24-50.

ShARP, G. (2014): «Otpor! Got its Symbols and Strategies from the Book, From Dictatorship to Democracy by Gene Sharp», Colors Magazine, 88, pp. 13-15.

ThackArA, J. (2000): Sin título. Barcelona, Actar - ADG FAD - Ayuntamiento de Barcelona.

Thoburn, N. (2014): «Unpopular Pamphlets», en Todoporlapraxis, ed., Disobedient Objects, en http://www.todoporlapraxis.es/ (última consulta, 17-10-2014).

VIRNO, P. (2003): Gramática de la multitud: para un análisis de las formas de vida contemporáneas. Madrid, Traficantes de Sueños.

Webster, M. (1964): Webster's New Practical School Dictionary. New York, American Book. 